\title{
Etiology of bacterial and parasitological pediatric diarrhoea in a tertiary care hospital
}

\author{
Shiv Kumar Chandrakar', Animesh Panda ${ }^{2}$, Smita Bawankar ${ }^{3}$, Dhruba Hari Chandi ${ }^{4}$ \\ ${ }^{1}$ Associate Professor of Pathology, CCM Medical College \& Hospital, Durg, ${ }^{2}$ Assistant Professor of Microbiology, CCM Medical College \& \\ Hospital, Durg, ${ }^{3}$ Assistant Professor of Microbiology, CCM Medical College \& Hospital, Durg, ${ }^{4}$ Demonstrator of Microbiology, CCM Medical \\ College \& Hospital, Durg
}

Background: Before starting to discuss about Diarrhoea, we have to remember diarrhoea is one of the main causes of morbidity and mortality in children. Aims \& Objective: The aim of this study was to determine the prevalence of intestinal parasitic and bacterial infections as cause of childhood diarrhoea. Materials \& Methods: During the study period, a total of 116 stool samples were collected and processed. Examined grossly and microscopically for presence of ova/cyst. They were also cultured on MacConkey agar and $E$. coli isolated were identified by standard biochemical tests. Results: Out of 116 stools samples, Entamoeba histolytica (63.33\%) and Giardia lamblia (23.33\%) were more common parasitic cause diarrhoea among children by either ova or cyst. E.coli $(74.13 \%)$ was common bacterial cause of diarrhoea among children. E. coli isolated in pure culture and sent for sero typing to Central Research Institute (CRI), Kasauli. Maximum percent were found to be pathogenic Escherichia coli i.e. EPEC $22.5 \%$. Conclusion: According to the result, the most common cause of bacterial diarrhoea is E.coli. EPEC were more prevalent followed by EHEC. Thus, macroscopic and microscopic stool examinations as well as culture were important for finding out the course of diarrhoea in childhood.

Key words: $E P E C$, Diarrhoea, Intestinal parasites, Bacterial \& $\mathrm{CCMMCH}$, Durg

\section{Access this article online}

Website:

http://nepjol.info/index.php/AJMS DOI: 10.3126/ajms.v7i3.14070 E-ISSN: 2091-0576 P-ISSN: 2467-9100

\section{INTRODUCTION}

The World Health Organization defined diarrhoea as the frequency of more than two unformed watery stools in a day or any voiding of watery stools if accompanied by fever, abdominal pain or vomiting., ${ }^{1,2}$

Infectious diarrhoea is one of the greatest causes of morbidity and mortality worldwide. The usual manifestations are vomiting, diarrhoea and abdominal discomfort. Amongst the various enteric bacterial pathogens, diarrhoeagenic strains of Escherichia coli (E. coli) are considerably responsible for causing bacterial diarrhoea. ${ }^{3}$

Campylobacter, Vibro, Aeromonas and Pseudomonas were also reported to cause Diarrhoeal diseases. Diarrhoeal diseases and dysentery are also caused by Entamoeba histolytica (amoebic dysentery), Cryptosporidium spp. In clinical bacteriology, the Shigellae are treated beside the Salmonellae, for both are intestinal pathogens and are isolated from faeces as non-lactose fermenting colonies on MacConkey agar media. Biologically, however, they are more closely related to the Escherichiae, with which they share antigens and some strains of which cause invasive, dysentery-like infection of the intestinal mucosa. ${ }^{4}$ Intestinal parasitic infections have always been an important public health problem in the tropics, particularly in developing countries like India, where the humid climate, the insanitary environment, and poor socioeconomic conditions contribute to the problem. Intestinal parasites may increase susceptibility to infections with other intestinal pathogens. In India malnutrition, unhygienic conditions, improper disposal of sewage and non availability of potable water supply in rural and urban areas are responsible for high rate of intestinal parasitic infections. It is therefore important to identify the problem and tackle it in the interest of public health. ${ }^{5,6}$ 
The main Aims and objectives of the study were to study the bacterial as well as of parasitic cause of childhood diarrhoea and to study the prevalence of diarrhoeagenic Escherichia coli.

\section{MATERIALS AND METHODS}

This study was conducted in Department of Microbiology CCM medical college kachandur. Fresh Stool specimens from 116 patients with age group from 1 to 11 years were received in Laboratory of Department of Microbiology and were included in this study during period of March 2014 to June 2015. Specimens were collected in special faeces collecting container (Hi media Pvt. Ltd). Patient data such as age, sex, address as well as information regarding sanitary facilities, past history of gastrointestinal illness, dietary habits was recorded at the time of receiving specimen.

Each stool specimen was examined by the following techniques for the presence of parasitic forms.

1. Gross examination: Stool was grossly examined for appearance as consistency, color and presence of blood or mucus.

2. Direct Microscopic examination were done by:

a) Saline preparation

b) Iodine preparation.

3. Stool samples were also examined after applying Formol-ether concentration technique. ${ }^{7}$

After Routine stool examination, bacterial culture was performed. When the specimen was formed or semi formed, a thick suspension was made of about $1 \mathrm{ml}$ of sterile peptone water. ${ }^{8}$

A loopful of the emulsified faeces or fluid specimen was inoculated on agar plates. MacConkey agar was used and other media such as Deoxycholate Citrate agar for Sbigella and Salmonella and the plates were incubated aerobically at $37^{\circ} \mathrm{C}$ overnight.

On the next day plates were examined for growth on MacConkey agar. Colonies were identified by colony morphology; gram stain of colony, motility test and different biochemical tests such as Indole, Citrate, Urease, TSI and PPA. Those which were identified as E.coli were sent to Central Research Institute. Distt.Solan: Kasauli (H.P) - 173204 for serotyping.

\section{RESULTS}

All 116 stool samples which were processed showed presence of either parasitic form or bacterial infections or both (refer Table 1). Out of total samples the infection were detected more in males (69) as compared to females (23), from Paediatric ward while that from PICU showed almost equal number from both gender.

From the Table 2. The total samples processed were from age group 1 year to 11 years. The age profile analysis showed that the age between 1-2 years showed maximum infection $(25.86 \%)$, followed by 6-7 years $(16.37 \%)$ and $10-11$ years $(12.93 \%)$ as shown in Table 2.

Table 3 shows that among 116 stool samples examined $30(25.86 \%)$ samples were detected to have intestinal parasites. Out of 30 positive samples, $19(63.33 \%)$ stool samples were positive for Entamoeba histolytica followed by Giardia lambia 7(23.33\%) and H. nana 1(3.33).

From the Table 4. Out of 116 bacterial isolates, 86(74.13\%) were Escherichia coli (E. coli) followed by Klebsiella

\begin{tabular}{|c|c|c|c|c|}
\hline Wards & $\begin{array}{c}\text { Male } \\
(n=84)\end{array}$ & $\begin{array}{c}\text { Female } \\
(n=32)\end{array}$ & $\begin{array}{c}\text { Total } \\
(\mathrm{N}=116)\end{array}$ & Percentage \\
\hline Paedia & 69 & 23 & 92 & 79.31 \\
\hline PICU & 15 & 09 & 24 & 20.68 \\
\hline
\end{tabular}

\begin{tabular}{|c|c|c|}
\hline Age & Total no. of isolates & Percentage \\
\hline 1 to 2 & 30 & 25.86 \\
\hline 2 to 3 & 7 & 6.03 \\
\hline 3 to 4 & 3 & 2.58 \\
\hline 4 to 5 & 4 & 3.44 \\
\hline 5 to 6 & 10 & 8.62 \\
\hline 6 to 7 & 19 & 16.37 \\
\hline 7 to 8 & 6 & 5.17 \\
\hline 8 to 9 & 11 & 9.48 \\
\hline 9 to 10 & 11 & 9.48 \\
\hline 10 to 11 & 15 & 12.93 \\
\hline Total & 116 & 100.00 \\
\hline
\end{tabular}

\begin{tabular}{lcc}
$\begin{array}{l}\text { Table 3: Prevalence of parasitic infections from } \\
\text { stool sample }(\mathrm{N}=30)\end{array}$ & No. of isolates & Percentage \\
\hline Name of parasite isolate & 16 & 53.33 \\
Cysts of Entamoeba histolytica & 3 & 10 \\
Cysts and trophozoites of & & \\
Entamoeba histolytica & 4 & 13.33 \\
Cysts of Giardia lambia & 3 & 10 \\
Trophozoites of Giardia lambia & 1 & 3.33 \\
Ova of H. nana & 3 & 10 \\
Ova of Taenia species & 30 & 100 \\
Total & & \\
\hline
\end{tabular}


spp. 19(16.37\%), Pseudomonas spp 6(5.17\%) and Proteus mirabilis $5(4.31 \%)$ as shown in Table 4. Almost all the sample shows the bacterial infection which was followed by the parasitic infection as a mixed infections.

Among 116 isolates 86(74.13\%) were Escherichia coli. Of the 86/116 E.coli isolated 80 were sent for serotyping to CRI, Kasauli. Among all the sero type strain Enteropathogenic E. coli (EPEC) were 22.5\%, untypable E. coli $(28.75 \%$ ) and Enterotoxigenic E. coli (ETEC were 5\% as shown in Table 5.

\section{DISCUSSION}

The present study showed that prevalence of parasitic and bacterial infections were most common between the age group 1-2 years $(25.86 \%)$ and 6-7 years $(16.37 \%)$. Out of the total 116 samples, Entamoeba histolytica (63.33\%) was most common parasite followed by Giardia lambia (23.33\%). Microscopic examination of stool specimens continues to be the main tool used in the laboratory diagnosis of intestinal infections.

\begin{tabular}{lcc}
$\begin{array}{l}\text { Table 4: Prevalence of bacterial infections from } \\
\text { stool sample }\end{array}$ \\
\hline Name of organism & No. of isolates & Percentage \\
\hline E. coli & 86 & 74.13 \\
Klebsiella spp. & 19 & 16.37 \\
Pseudomonas spp. & 6 & 5.17 \\
Proteus mirabilis & 5 & 4.31 \\
Total & 116 & 100 \\
\hline
\end{tabular}

\begin{tabular}{llcc}
\multicolumn{3}{l}{ Table 5: Serotypes characteristic of the } \\
diarrhoeagenic & E. coli categories $(\mathrm{N}=80)$ & \\
\hline E. coli strain type & O Serogroup & No. of strains & No. \\
\hline ETEC & O8 & 2 & 4 \\
& O166 & 1 & \\
EPEC & O60 & 1 & 18 \\
& O18 & 2 & \\
EHEC/STECNTECC & O26 & 12 & \\
& O56 157 & 4 & 12 \\
& O87 & 3 & \\
& O116 & 1 & \\
O10 & 1 & \\
EAEC & O113 & 5 & \\
EIEC & O56 & 1 & \\
E. coli & O136 & 0 & \\
& O143 & 1 & 4 \\
& O9 & 3 & \\
E. coli & O33 & 1 & 7 \\
Non E. coli & O30 & 1 & \\
\hline
\end{tabular}

Amongst the bacteria cause of diarrhoea, E. coli was (74.13\%) followed by Klebsiella spp (16.37\%). This study also showed that among the bacterial infections caused by EPEC (22.5\%) was more prevalent followed by EHEC (15\%) in children, which are the proven causes of childhood diarrhoea in developing countries.

In the study of Ogullesi Tinuadee et al (2006) shows that $23.3 \%$ had parasite in which Entamoeba histolytica $65.7 \%$ followed by Ascaris lumbricoides 18.6\% and Giardia lamblia $7.1 \%$.

In the study of A. Samie et al (2009) shows that Entamoeba bistolytica and Cryptosoridium species (34.2\% and 25.5\% respectively) were most commonly isolated parasites. ${ }^{10}$ In study of Anuradha S. De. et al (2010) also shows that 43\% were Diarrhogenic E. coli and among them 37.21\% were STEC. ${ }^{11}$

Another similar study of Samer A Al- Hilali et al (2011) shows that $81.6 \%$ E.coli were isolated in which $3.4 \%$ were EPEC. ${ }^{12}$ Where as in study of P. Rjendra et al (2012) shows that Campylobacter species are the main cause of bacterial gastroenteritis. ${ }^{13}$

\section{CONCLUSION}

Diarrhoea in children could be multifactorial. Though easier methods of diagnosis and treatment are available for parasitic infestations, they are not yet eradicated. Hence continued surveillance is necessary for studying epidemiological factors for diarrhoeal diseases as well as methods of control. Diarrhoeal diseases can be minimized by educating community on proper personal hygiene and suitable local control strategies should be set up.

\section{ACKNOWLEDGMENT}

We thanks and appreciation to technical staff \& paediatrics of our CCM college \& hospital.

\section{REFERENCES}

1. W.H.O. Scientific working group parasite related diarrhoea Bull World HIth Org 1980; 58:819-830.

2. W.H.O. The management and prevention of diarrhoea. Practical guidelines $3^{\text {rd }}$ Edn. Switzerland. 1993.

3. Diarrhoea: Why children are still dying and what can be done. The United Nations Children's Fund (UNICEF)/World Health Organization (WHO), 2009.

4. Abdullahi M, Olonitola SO and Inabo IH. Isolation of bacteria associated with diarrhoea among children attending some hospitals in kano metropolis, kano state, Nigeria. Bayero Journal of Pure and Applied Sciences 2010; 3(1): 10 - 15.

5. Kaur R, Rawat D, Kakkar M, Uppal B and Sharma VK. Intestinal 
parasites in children with diarrhoea in delhi, india, Department of Microbiology, Maulana Azad Medical College and Lok Nayak Hospital, New Delhi, India 2006.

6. Acute diarrhoea in adults and children: a global perspective. World Gastroenterology Organisation Global Guidelines. February 2012.

7. Rajesh K and Ajit D. Medical Parasitiology. $2^{\text {nd }}$ edition. India, 2008, pp 17-43.

8. Monica Cheesbrough. District Laboratory Practice in Tropical Countries. $2^{\text {nd }}$ edition update 2012-part 2.

9. Tinuade $\mathrm{O}$, Jhon $\mathrm{O}$, Saheed $\mathrm{O}$, Oyeku $\mathrm{O}$, Fidelis $\mathrm{N}$ and Olabisi $\mathrm{D}$. Parasitic Etiology of Childhood Diarrhoea. Indian Journal of Pediatrics 2006; 73: 1081-1084.

10. Samie A, Guerrant RL, Barrett L, Bessong PO, Igumbor EO and Obi CL. Prevalence of Intestinal Parasitic and Bacterial
Pathogens in Diarrhoeal and Non-diarroeal Human Stools from Vhembe District, South Africa. J Health Popul Nutr 2009; 27(6):739-745

11. Panda S, Dharma Rao U and Rama Sankaram K. Prevalence of Intestinal Parasitic Infections among School Children in Rural Area of Vizianagaram. Journal of Pharmacy and Biological Sciences 2012; 3(3): 42-44.

12. Hilali A, Samer $A$ and $M$ Almohana Ali. Occurrence and molecular characterization of enteropathogenic Eschericha coli serotypes isolated from children with diarrhoea in Najaf, Iraq. Indian Journal of Medical Microbiology 2011; 29(4): 383-388.

13. Rajendran $P$, Abji S, George AT, Rajan DP, Kang $G$ and Ajjampur SS. Detection and species identification of Campylobacter in stool samples of children and animals from Vellore, South India. Indian Journal of Medical Microbiology 2012; 30(1): 85-88.

\section{Authors Contribution:}

AP, SKC- Conceptualized study, literature search, statistically analyzed and interpreted, prepared first draft of manuscript and critical revision of the manuscript; SB, DHC- Concept, collected data and review of literature and helped in preparing first draft of manuscript. 